\title{
Thomas Aquinas and William E. Carroll on Creatio ex Nihilo: A Response to Joseph Hannon's "Theological Objections to a Metaphysicalist Interpretation of Creation"
}

\section{Ignacio Silva}

To cite this article: Ignacio Silva (2021): Thomas Aquinas and William E. Carroll on Creatio ex Nihilo: A Response to Joseph Hannon's “Theological Objections to a Metaphysicalist Interpretation of Creation", Theology and Science, DOI: 10.1080/14746700.2021.1910908

To link to this article: https://doi.org/10.1080/14746700.2021.1910908

\section{冊 Published online: 11 Apr 2021.}

\section{Submit your article to this journal $\square$}

Џلl Article views: 4

Q View related articles $₫$

View Crossmark data ¿ 


\title{
Thomas Aquinas and William E. Carroll on Creatio ex Nihilo: A Response to Joseph Hannon's “Theological Objections to a Metaphysicalist Interpretation of Creation"
}

\author{
Ignacio Silva
}

\begin{abstract}
Joseph Hannon has expressed a most surprising objection to Aquinas scholar Prof William E. Carroll in his latest paper "Theological Objections to a Metaphysicalist Interpretation of Creation." The main claim is that Prof. Carroll misunderstands Aquinas' doctrine of creatio ex nihilo by reducing it to a metaphysical notion, rather than considering it in its full theological sense. In this paper I show Hannon's misinterpretation of Carroll's and Thomas Aquinas' thought, particularly by stressing the dependence that the doctrine of providence through secondary causes has on the doctrine of creatio ex nihilo.
\end{abstract}

Joseph Hannon has expressed a most surprising objection to Aquinas scholar Prof William E. Carroll in his latest paper "Theological Objections to a Metaphysicalist Interpretation of Creation." "The main claim is that Prof Carroll misunderstands Aquinas' doctrine of creatio ex nihilo by reducing it to a metaphysical notion, rather than considering it in its full theological sense. Bold objections such as those present in Dr. Hannon's paper require not only a profound understanding of Aquinas' thought, but a thorough reading of Prof Carroll's own work. I believe Dr. Hannon's paper, however, lacks both these features, as almost anyone well acquainted with Aquinas' metaphysics of creation and with Prof Carroll's understanding of it could note. ${ }^{2}$

I hope to show in the pages to follow that this is an unfortunate misreading of Prof Carroll's teaching on the subject. Two comments are worth mentioning from the outset. First, Prof Carroll has written extensively on this subject for over forty years in many publications and lectured on it around the world; and second, as far as I know, he has never received any objection against his teaching on the matter, a fact that places his interpretation of this doctrine not only at the mainstream of Aquinas scholarship today, but also at the forefront of the "regained momentum in recent literature" for Thomistic perspectives on science and theology, as David Fergusson has put it lately. ${ }^{3}$ Prof Carroll is, together with Prof Michael Dodds, at the leadership of this new Thomistic movement within theology and science. ${ }^{4}$ I shall follow the order Dr. Hannon used in his own paper to show the shortcomings of his arguments against Prof Carroll. ${ }^{5}$

Perhaps Dr. Hannon's most important worry, stated in the introduction, is to preserve God's ability to act in the world against what he sees as the alignment of Thomism with naturalism. That is, Dr. Hannon sees in Prof Carroll's defence of the doctrine of creatio ex nihilo and the subsequent notion of the autonomy of nature in its activity a necessary 
rejection of God's omnipotence, in the sense that were Prof Carroll's teachings correct, God would not be able to involve himself in the development of the universe and of human history. This would indeed be something unacceptable and certainly undesirable. As I will show, Dr. Hannon would do well in dropping his worry, since the very teachings of Prof Carroll hold precisely what he wants to defend.

Unfortunately, to argue for his position, Dr. Hannon frequently misquotes Prof Carroll and misinterprets his sayings on Aquinas. Take, for instance, the following passage from the first section, on page 292: "Carroll is reticent about whether creatio ex nihilo means that God actually produced anything material." As Carroll repeatedly notes when he writes about creation, God, as Creator, causes all things to be in whatever way or ways they are. "All things" obviously includes material things, as Aquinas explains when analysing the notion of creation and its relation to matter in his Summa Theologiae I, q. 45, a. 4, ad 3: "matter does not exist except by creation; for creation is the production of the whole being, and not only matter." Ironically, Hannon continues his argument thus: "More likely, he [Prof Carroll] thinks that all that what God did was to provide the necessary cause that allows anything to exist at all." To say that such an assertion is "more likely," is extraordinary since nowhere in his works does Prof Carroll claim that God only provides a necessary cause for things to exist. On the contrary, as I showed above, Prof Carroll holds that God's act of creation involves the putting things into existence in their whole being and, consequently, in all the operations they perform, as I will show below.

It seems to me, rather, that Dr. Hannon has certainly misread Prof Carroll's work. To understand my claim, consider the way Dr. Hannon describes creation, in a previous paragraph on the same page, as something that happened in the past affirming that "Creatio ex nihilo, as properly understood, therefore means that God created all things" (note the past tense of the verb "to create" and the way one must understand this definition: "properly"!). Such statements cannot be further away from Prof Carroll's own thinking, who consistently highlights that God's creation is a continuous act, the act of giving and sustaining things in existence, and thus not simply an event in the past. On many a page one can read statements in this regard: "Creation is not exclusively some distant event; it is the continual, complete causing of the existence of whatever is. In a fundamental sense, creation is not really an event at all." 6

Dr. Hannon follows his statements with what is, perhaps, the strongest evidence that he has not fully understood Prof Carroll's teachings on Aquinas (or even Aquinas' own teaching): "What Aquinas was not doing, however, was insisting that creation was limited to a metaphysical explanation as to why anything existed at all - the crux of Carroll's argument." Again, anyone who has taken Prof Carroll's work in their hands knows of his paradigmatic insistence that Aquinas distinguished between a philosophical and a theological sense of what it is to create. This distinction is paradigmatically presented in Aquinas' commentary on Peter Lombard's Sentences (In II Sent., dist. 1, q. 1. a. 2): "Not only does faith hold that there is creation, but reason also demonstrates it." Consider the following explanation of these notions in the words of Prof Carroll:

Aquinas points out that there are two senses of creation out of nothing, one philosophical, the other theological. The philosophical sense simply means that God, with no material cause, makes all things to exist as entities that are radically different from His own being yet completely dependent upon His causality ... The theological sense of creation denies 
nothing of the philosophical sense but merely adds to it the notion that the created universe is temporally finite. This theological sense of creation cannot be proven philosophically; it can only be known through revelation. ${ }^{7}$

Just to avoid the temptation of accusing Prof Carroll of neglecting the theological sense in his analysis of creation (as Dr. Hannon seems to be doing at some points in his text), consider the following passage:

The affirmation in faith that the universe has a temporal beginning perfects what reason knows about creation. Thomas's theological analysis of creation is much richer than just the recognition that the world has a beginning. He sees all things coming from and returning to God. Furthermore, the entire universe of creatures, spiritual and material, possesses a dynamic character, analogous to the internal dynamism of the Divine Persons of the Trinity. With the eyes of faith one sees the whole created order as 'footsteps' of the Trinity. Throughout, Thomas's theological understanding of creation is informed by his philosophical analysis; after all, Thomas is a philosopher because he is a theologian. ${ }^{8}$

It should not be necessary to continue my critique of this paragraph, but unfortunately, it is precisely where Hannon misquotes Aquinas himself! Hannon quotes Aquinas saying that "he [Aquinas] then explains that, 'God created all things together so far as regards their substance in some measure formless'." If one were aware of Carroll's distinction between both senses of creation, it would be evident that in Summa Theologiae I, q. 74, a. 2 (the precise passage Dr. Hannon uses to attempt a refutation of Prof Carroll's arguments, and not a. 3 to which Dr. Hannon wrongly refers in his text), Aquinas is doing hermeneutical theology, and not a metaphysical analysis of the notion of creation, as the whole article shows, in which Aquinas attempts to meet the arguments of the holy Fathers in explaining the matter of how to understand that Scripture refers to six days in the narrative of creation in Genesis 1 rather than one, since God is said to create all thing simultaneously. Dr. Hannon should have been more careful in both his readings of Aquinas and Prof Carroll, and in his explanation of both their positions. This simple detail would have sufficed to avoid such misunderstanding.

Hannon finishes this section of the paper accusing Prof Carroll of offering a "gross mis-interpretation of his [Aquinas'] ontology of creation" with his understanding of the idea that creation is not a change, because he (Prof Carroll) does not pay attention to the theological discussions Aquinas offers, which, for Dr. Hannon, show that God does effect change in the world by creation. Dr. Hannon's problem is clear: he identifies the philosophical with the theological understanding of creation, misreading both Aquinas and Prof Carroll's ideas.

In the following section Hannon strongly affirms on page 294 that "Carroll fails to explain why an eternally existing universe would have to depend on God as the cause for its existence," though acknowledging, on the same page, that Prof Carroll understands that "Being itself needs a cause." If this is not the reason Dr. Hannon is looking for, then he clearly does not understand Aquinas' discussion on the eternity of the universe, something which Prof Carroll discusses at length in many of his publications. In these discussions Aquinas argues that precisely because creation is the giving of being to things created, this giving can be eternal or have a temporal beginning. This is the basic analysis of the philosophical sense of creation, a sense that prescinds from any question of the universe's temporality. Theologically speaking, however, one can know that creation has a temporal beginning, a fact that Prof Carroll acknowledges all over his 
work (written and spoken throughout the world), even when philosophically, an eternal creation is not contradictory: "From his earliest to his last writings on the subject, Thomas maintains that it is possible for there to be an eternal, created universe. On the basis of faith Thomas holds that the universe is not eternal. But he thinks that God could have created a universe that is eternal. Although reason affirms the intelligibility of an eternal, created universe, Aquinas thought that reason alone leaves unresolved the question of whether the universe is eternal ... Near the end of his career, in De aeternitate mundi, Thomas will take up, in his most sophisticated treatise on the subject, the intelligibility of an eternal, created universe. There he will write: 'to say that something has been made by God and that it has always existed, is not logically inconsistent.'

Hannon might reply that his use of Prof Carroll's words "Being itself needs a cause" referred to the question of why God does not need a causal explanation. A short linguistic turn might be helpful here. As we are all well aware, the English language uses the same term "being" for two very distinct and technical Latin terms that Aquinas distinguishes, namely "esse" and "ens." It seems rather evident that Prof Carroll's claim that "being itself needs a cause" refers to "ens" and not to "esse," hence requiring not a causal explanation of God's being (esse), but rather a casual explanation of the being of created things, each of which is an ens. Certainly, Hannon is aware of this difference as the end of his paragraph shows, but he somehow accuses Prof Carroll of not knowing of it, something rather odd to say about an expert on Aquinas, who has written that God is not "an entity among other entities."

Having in mind Aquinas' and Prof Carroll's discussions about the eternity of the world, I must say that it is quite ironic to find a sort of defence of the kalam cosmological argument in Hannon's paper, arguing against Prof Carroll that the theory of Big Bang could offer any insight into the doctrine of creatio ex nihilo. Hannon argues that "if the Big Bang does represent the moment at which matter, energy, space and time were all brought into existence," then William Lane Craig would be correct, and Prof Carroll wrong in affirming that "we do not get closer to creation by getting closer to the Big Bang." I fail to see the motivation behind Hannon's statement in favour of the kalam cosmological argument, but I do not fail to see that Hannon, even when acknowledging that the Big Bang theory receives different interpretations as to what it means, is affirming (conditionally) something with which scientists are not in common agreement. This is precisely the peril against which Prof Carroll warns us: not to make our metaphysics and theology dependant on an unresolved scientific theory (as any other scientific theory, since all of them are unresolved to a certain extent), following on Aquinas' own strategy, because, as Prof Carroll explains,

Thomas thinks that reason alone cannot know whether or not the universe is eternal. It is, he thinks, an error to try to reason to creation ex nihilo by attempting to show scientifically that the world has a temporal beginning. Nevertheless, for Thomas, reason can show, in the discipline of metaphysics, that the world has an origin: that it is created ex nihilo. The affirmation in faith that the universe has a temporal beginning perfects what reason knows about creation. ${ }^{11}$

After all, if, as Hannon accepts, God is continuously creating the universe, then there is no need to conflate the origin of the universe, which is for both Aquinas and Prof Carroll in God, and the beginning of the universe, which according to the Big Bang theory happened 14 billion years ago. ${ }^{12}$ Even the father of the Big Bang theory, Catholic priest and cosmologist Georges Lemaitre, acknowledges this distinction and is unwilling to identify his "primeval atom" with the moment of creation! ${ }^{13}$ 
Still, if we were to assume Hannon's hypothesis that the Big Bang represents the moment in which the universe's matter, energy, space and time were brought into existence and thus identify it with the act of creation, then Prof Carroll would certainly be glad to say that creation in this sense is not a change, and hence not an act within the natural world. The issue is, once again, that scientists today are not certain that Hannon's hypothesis is correct, and in fact, many are suggesting alternative cosmological models for the beginning of the universe in which we live. As Prof Carroll notes, many cosmologists often speak of what happened before the Big Bang.

Ultimately, it seems that Hannon is falling into the trap of a god-of-the-gaps, as is evident from the following argument about the origin of life in his text. He claims on page 295 that the organic origin of life on earth is such an exceptional historical event that it is "a rare example of where a supernatural intervention does at least appear possible due to the lack of a valid scientific explanation." This statement is far too clear: there is no scientific explanation, hence we can invoke on God to fill in the gap. I will neither go into the fate that such explanations underwent in history (think of Newton's God as the paradigm) nor into the theological difficulties this approach brings for the methodological relations between science and theology, for both these themes have been extensively explored in the past. Let me simply suggest that this strategy has brought no good at all to theology throughout history. If any, this is doubtless a good lesson to be learnt from some past interaction between science and theology. Am I, then, claiming that science can explain the origin of organic life on earth? Yes, it might in some future days. Still, I do not agree with the claim that if this is true, then "the origin of life has nothing directly to do with any divine plan," as Hannon affirms on the same page. As I will discuss bellow, in the perspective of Thomas Aquinas (and of Prof Carroll), God does make use of secondary created causes to instrument his plan for creation, including the origin of organic life and human beings.

It is here where Hannon mixes up the issues of extrinsic design and intrinsic teleology, two very distinct notions that need to be accounted for, and the difference of which needs to be acknowledged, if one wants to assume Aquinas' philosophy as one's own. As I have shown elsewhere, ${ }^{14}$ these two terms are rather different, and Aquinas would favour understanding God's providence to work through intrinsic teleology, through the act of creation in the way that Prof Carroll understands it, while from the seventeenth century authors such as Robert Boyle would assume that God extrinsically imposes some external teleology to created things. This difference has to do with the distinct natural philosophies assumed in each epoch, namely an Aristotelian framework in which formal and final causes were proper to created things, and an atomistic philosophy in which atoms were conceived as being purely pieces of matter without formal causes, needing, hence, an extrinsic influx from God to be directed towards God's end. If we acknowledge this distinction, then we can see why Hannon's analysis of the Aquinasinspired Catholic Catechism claim that "God is the first cause who operates in and through secondary causes" fails. God acts "as the over-arching providential cause, giving direction to a series of ordinary causes that were themselves completely natural," not as Hannon affirms because natural causes are insufficient. This would mean that, to be able to act, God requires insufficient natural causes, a rather odd claim within a Thomistic analysis. Instead, the Catechism's claim means that God, by creating natural tendencies in natural things, providentially guides the development of 
the world and human history. ${ }^{15}$ Could God have used this metaphysical mechanism to give place to the origin of organic life on earth? Certainly.

Hannon moves on then to affirming that Aquinas upholds the possibility of miracles, in the sense that God could produce things that go beyond the natural created powers, hinting that Prof Carroll denies such doctrine when he (Prof Carroll) insists that God cannot be assumed to be a cause among causes. I certainly fail to see how this is so, given that for Aquinas (and Prof Carroll) even when God produces a miracle God acts as a first cause, creating the whole being of that miracle at that precise point, and hence not as a cause among causes, that is, as a created cause that is required to act according to the order of nature. In fact, it would be surprising to find anyone within Thomistic circles who would be happy to affirm that God requires the insufficient agency of natural causes to produce a miracle, as Hannon seems to suggest. God can perform any miracle at any time regardless of the sufficiency or insufficiency of natural causes. When Prof Carroll says that God is not a cause among causes, he is not denying that God's causality is essential for the existence and operations of all creatures; rather, he is pointing to the fact that God is not a cause in the same way that creatures are causes.

The final paragraph of Hannon's second section summarises his worry. He insists that Prof Carroll's teachings mean that God is precluded from acting in the created universe in any sense but for a distant and remote creative act. In his words, Carroll's "extreme naturalism precludes any possibility that God can causally act to effect change in the material world. The only thing that God can do is act to prevent everything from becoming nothing." What Hannon fails to see with his claims is that Aquinas' doctrine of providence through secondary causes flows seamlessly from his doctrine of creatio ex nihilo, which is also the spirit of the Catholic Catechism's statements, and as Prof Carroll teaches:

Created beings can and do function as real secondary causes, causes which can be discovered in the natural sciences. God as cause so transcends the created order that He can cause creatures to be causes ... Creatures are what they are (including those which are free), precisely because God is present to them as cause. Were God to withdraw, all that exists would cease to be. Creaturely agency and the integrity of nature, in general, are guaranteed by God's creative causality. ${ }^{16}$

One only needs to look at the treatment that Aquinas offers in his explanations of providence in the Summa Contra Gentiles or the Disputed Questions on the Power of God (or any other place where Aquinas discusses the doctrine of providence), to see the intimate relation that it has with his doctrine of creation as Prof Carroll explains it.

Hannon starts the following and last section of his paper by referring to Prof Carroll's caution in reading Scripture, particularly the account of creation in Genesis 1. It would have been appropriate, I believe, to note how Prof Carroll's caution follows in the steps of Thomas Aquinas', who precisely in the question of the Summa Theologiae to which Hannon referred in the previous section is as cautious as Prof Carroll. Just after considering, in his Summa Theologiae I, q. 74, a. 2, the different approaches that the Fathers take on the number of days that God used in creating the universe, Aquinas warns us that all their "arguments must be met," as if offering the advice of not rushing in our readings of the sacred text but consider the arguments with care and caution. Aquinas has this same attitude towards Scripture all throughout his work, from his early writings commenting on Peter Lombard's Sentences to the end of his Summa Theologiae. Still, Hannon uses his 
particular take on Prof Carroll's attitude to Scripture to advance a new objection to his understanding of creation and divine action in the world.

Hannon boldly affirms by the end of page 297 that Prof Carroll's "strict demarcation between the causality of divine action at a purely metaphysical level and secondary causes at a physical level is unjustified and unnecessary since they are likely intimately intertwined." This statement would certainly be surprising for many of Prof Carroll's readers, given his constant insistence that

God does not only give being to things when they first begin to exist, He also causes being in them so long as they exist. He not only causes the operative powers to exist in things when these things come into being, He always causes these powers in things. Thus, if God's creative act were to cease, every operation would cease; every operation of a thing has God as its ultimate cause. ${ }^{17}$

Prof Carroll, following on Aquinas' teaching, does nothing but affirm the most intimate relation between the first cause and secondary causes, and hence it is rather Hannon's claim that is simply "unnecessary and unjustified." One needs only to consider the following words by Prof Carroll:

God is immediately active in all things and, in an important sense, God is more intimate to each creature than a creature is to itself. God, as the cause of each creature's being, is present at the very center of each creature's being. He is more interior to things than they are to themselves. ${ }^{18}$

These words echo Aquinas' own, for instance, when commenting on the initial lines of the Gospel of John:

God acts in all things as an interior agent, because he acts by creating. Now to create is to give being (esse) to the thing created. So, since esse is most intimate in each thing, God, who by acting gives esse, acts in things as an intimate agent, ${ }^{19}$

or in his Disputed Questions on Truth, where he further qualifies this statement in the way Prof Carroll understands Aquinas' doctrine: "God Himself is the proper and immediate cause of each thing, and in some way He is more intimate to each thing than the thing is to itself, as Augustine says." 20

Hannon follows listing a number of instances in which God is said to act in the world directly (the Incarnation and the creation of human souls). Still, he either fails to recognise that these are instances of miraculous divine action, something to which Prof Carroll has never objected, or he assumes that God's miraculous actions are not instances of his acting as first cause. The former seems certainly not to be the case, since Hannon appears to defend the fact that God does act miraculously in the universe against some rather illcrafted version of what Prof Carroll teaches. So, the latter option seems to be what Hannon holds. The problem here is that Aquinas (and Prof Carroll) teaches that God acts as first cause in all His actions, as the quotation above of his commentary to the Gospel of John shows. Of course, God is the creator of the human soul in a real sense (something that worries Hannon to a great extent), but, in Aquinas' doctrine, this activity of the creation of the human soul is a miraculous action in the manner of the first cause, that is, in the giving of esse.

Hannon's worries seem to reduce to the fact that he understands the metaphysical doctrine of creatio ex nihilo as Prof Carroll teaches it to be nothing but a metaphorical 
account of creation, even suggesting that Prof Carroll's account is reduced to the NeoPlatonic doctrine of emanation. This is clearly not the case, as I have shown in this paper. Ironically, still, Aquinas himself uses the language of emanation to speak of creation! When explaining his own doctrine of creation in the very Summa Theologiae I, q. 45, a. 1, Aquinas affirms, among the fourteen times that he uses the term "emanation" in that question, that "this emanation of things we designate with the name of creation."

Ultimately, Hannon believes that in Prof Carroll's account of Aquinas' doctrine of creation, "we have the ultimate retreat since divine agency is banished to an obscure place where science can never touch it," because of Prof Carroll's "insistence that creation can never involve change, and that all change within the world must be entirely natural." But such a claim involves a false dichotomy. Here again we see Hannon's temptation for a "God-of-the-gaps," for he alludes to God's action being subject to the scrutiny of the natural sciences. By contrast, instead of considering these features of Aquinas' doctrine a weakness, Prof Carroll believes that they are its major strength, because they show how creatures are real causes, created to be such by God's own causal power. Indeed, as Prof Carroll points out, all changes are caused by God, but not in such a way as to deny the reality of natural causes. God causes changes to be the changes that they are, but such divine causing is not itself a change. Prof Carroll's teachings point to the metaphysical fact that the creative act, in its most profound and real sense, can never involve a change, because changes require something that changes, whereas the divine act of creation is, absolutely speaking, out of nothing else but the power and goodness of God. Were God in need of some kind of stuff to create at any point in the history of the universe (or in need of some kind of insufficiency in natural causal processes to act providentially within that universe), then God would not be, absolutely speaking, the origin of all things that exist and act. Aquinas' doctrine, represented and explained in Prof Carroll's works, detracts neither from the power of natural created causes to be such (and hence subject to the inquiry of the natural sciences), nor from the power of God, who is active in the created universe both by performing miracles and in and through secondary created causes, always as the first cause of everything that is.

\section{Notes}

1. Joseph Hannon, "Theological Objections to a Metaphysicalist Interpretation of Creation," Theology and Science 18:2 (2020), 290-302. I would strongly recommend anyone interested in my arguments to read Dr. Hannon's paper before reading mine.

2. As a probably unnecessary, though due, disclosure note, I must say that Prof Carroll was my doctoral advisor at Oxford and a mentor even from before. I do not believe, however, that this distorts my readings of his and Aquinas' works. In fact, I have criticised Prof Carroll in my own work, and entered into very fruitful discussions with him afterwards.

3. David Fergusson, The Providence of God: A Polyphonic Approach (Cambridge: CUP, 2018), 88.

4. As a quick note, I should point out the infelicitous mis-attribution to Aaron Klink of Michael Dodds' wonderful work Unlocking Divine Action. Contemporary Science and Thomas Aquinas (Washington DC: CUA Press, 2012), perhaps the most important work on Aquinas and contemporary science, in footnote 7 of Dr. Hannon's paper.

5. As a short, and probably unfair, profile of Prof Carroll's academic achievements, I should mention that his essays and books on Thomas Aquinas on creation have appeared in 12 different languages, including Persian, Russian, and Chinese, in various peer-reviewed 
journals. He has given special lectures on this subject to diverse audiences at the Pontifical Academy of Sciences, the Vatican Observatory School on Astrophysics, the Royal Institute of Science and Technology in Stockholm, and the Royal Society in London, as well as at a large number of elite universities in the United States and Canada, Europe, Central and South America, and China. Over the past twenty years he has been a Research Fellow at the Aquinas Institute in Blackfriars at the University of Oxford, organising annual lectures and colloquia on the thought of Thomas Aquinas, which involved more than 70 leading scholars of Aquinas from all over the world. He and Steven Baldner produced an English translation and extensive commentary on Aquinas' first magisterial treatment of creation, Aquinas on Creation, published in 1997 by the Pontifical Institute of Mediaeval Studies, Toronto.

6. William E. Carroll, "Science and Creation: the Medieval Heritage," in The Oxford Handbook of Abrahamic Religions, eds. Adam J. Silverstein and Guy G. Stroumsa (eds.), (Oxford University Press, 2015), 355-372, 368.

7. William E. Carroll, and Steven Baldner, "Introduction," in their edited volume Aquinas on Creation. Writings on the "Sentences" of Peter Lombard - Book 2, Distinction 1, Question 1 (Toronto: Pontifical Institute of Mediaeval Studies, 1997), 1-62, 42.

8. Carroll, "Science and Creation," 369.

9. Carroll, "Science and Creation," 366-367. My emphasis.

10. William E. Carroll, "After Darwin, Aquinas. A Universe Created and Evolving," in Darwin in the Twenty-First Century: Nature, Humanity, and God, eds. Phillip R. Sloan, Gerald McKenny and Kathleen Eggelson (Notre Dame, IN: The University of Notre Dame Press, 2015), 299-337, 307-308.

11. Carroll, "Science and Creation," 369.

12. Prof Carroll explains these ideas in the first pages of his "Aquinas and Contemporary Cosmology: Creation and Beginnings," in Georges Lemaître: Life, Science and Legacy, eds. Rodney D. Holder and Simon Mitton (Springer, 2013), 75-88.

13. As he expressed in a posthumously published manuscript. See Carroll, "Aquinas and Contemporary Cosmology," 77.

14. See my "From Extrinsic Design to Intrinsic Teleology," European Journal of Science and Theology 15:3 (2019), 61-78.

15. See Simon Maria Kopf, Divine Providence and Natural Contingency: New Perspectives from Aquinas on the Divine Action Debate (DPhil Thesis, Oxford, 2019).

16. Carroll, "Science and Creation," 368. Prof Carroll might not highlight this part of Aquinas' doctrine to the likings of Hannon, but this does not mean that he neglects it or that he does not acknowledge it.

17. Carroll, "After Darwin, Aquinas," 317.

18. Carroll, "After Darwin, Aquinas," 314.

19. Thomas Aquinas, Super Evangelium S. Ioannis lectura, c. 1, 1. 5. In S. Thomae de Aquino, Opera Omnia, recognovit et instruxit Enrique Alarcón automato electronico Pompaelone ad Universitatis Studiorum Navarrensis aedes a MM A.D. Fundación Tomás de Aquino, 2019. https://www.corpusthomisticum.org/iopera.html. My translation.

20. Thomas Aquinas, Disputatae Quaestiones de Veritate, q. 8, a. 16, ad 12. In S. Thomae de Aquino, Opera Omnia. My translation.

\section{Disclosure Statement}

No potential conflict of interest was reported by the author(s).

\section{Notes on contributor}

Ignacio Silva is an Associate Professor of Theology and Science, Instituto de Filosofía, Universidad Austral. 